\title{
Environmental, Economical and Social Implication of Jatropha: A Systematic Review
}

\author{
Yihunie Bekalu Babil \\ Forest Products, Innovation research and training center, Ethiopian Environment and Forest Research Institute. \\ P.O. box 2322 Addis Ababa, Ethiopia
}

\begin{abstract}
Jatropha curcas: from leaves, latex, roots, and seeds different bioactive or commercially important ingredients have been extracted using different methods. Jatropha curcas $\mathrm{L}$ is a multipurpose plant and a member of the family Euphorb eaceae with several application and considerable potential. The plant produces many useful products, especially the seed, from which oil can be extracted; this oil can be used as a feed stock for biodiesel. The extracted oil can also be used for making soap, glue, dye, etc. The leaves shoot latex, roots and seed oil has medicinal properties. The fruit exo carp (coat), seed shell and processed seed cake are rich in nitrogen, phosphorous and potassium and can be used as fertilizer. Newly developed biotechnological processes related to the exploitation of J. curcas include the genetic improvement of the plant, biological pest control, enzymesupported oil extraction, anaerobic fermentation of the press cake and the isolation of anti inflammatory substances and wound-healing enzymes. In General Jatropha curcas is a quick-growing and popular tree. It is a traditionally important medicinal plant and having various commercial applications.
\end{abstract}

Keywords: Jatropha, Application, Economic, Extraction

DOI: $10.7176 / \mathrm{JRDM} / 74-01$

Publication date:March $31^{\text {st }} 2021$

\section{INTRODUCTION}

Jatropha curcas L is a multipurpose plant and a member of the family Euphorbeaceae with several attributes and considerable potential. The present review article discussed the reported recent research on the utilization of various parts of jatropha plant for different applications. J. curcas L is a tropical plant that can be grown in marginal lands of low to high rainfall areas and can be used as a commercial crop. The plant produces many useful products, especially the seed, from which oil can be extracted; this oil can be used as a feed stock for biodiesel. The extracted oil can also be used for making soap, glue, dye, etc. The leaves, shoot latex, roots and seed oil has medicinal properties. The fruit exocarp (coat), seed shell and processed seed cake are rich in nitrogen, phosphorous and potassium and can be used as fertilizer. The plant can be used to prevent and/or control erosion, to reclaim land, grown as a live fence to protect agricultural fields from farm animals and can be planted as an alternate commercial crop. It could provide employment, save foreign exchanges, improve environment and develop the socio-economic status of poor resource farmers in developing countries. Each and every part of the plant is useful in some ways. Even the seed cake produced as a byproduct is used as an excellent organic fertilizer. Some parts of the plant are used for medical purposes. In short all the parts of the jatropha plant can be utilized for different applications (A. K. M. A. Islam,2010).

$J$. curcas is a promising species because of its useful and profitable by-products. The chemical composition of various parts of $J$. curcas plant shows which have many Medicinal and industrial applications. Jatropha Curcas L. has been widely accepted as a favorite agricultural solution for all subtropical and tropical locations for sound logical reasons (Dove Biotech). It requires only moderate rainfall (approx. 600mm only) and can withstand long periods of drought, but will thrive under higher rain fall, It is a permanent, uncomplicated crop that, once established, can last for many decades. It therefore eliminates normal annual seedbed preparations and planting, Due to its low demand on soil fertility, it is ideal to replant marginal lands to prevent desertification.

Jatropha oil has various uses and apart from its use as a bio fuel, the oil has been used to produce soup, medicine and pesticides. The utilization of various parts of J. curcas L. is reviewed here, to know the potentials for improving economic situation of various tropical and subtropical countries. Although there have been increasing investments and policy decisions concerning the use of jatropha as an oil crop, they have been based on little evidence-based information. There are many knowledge gaps concerning the best production practices and the potential benefits and risks to the environment. Equally troubling is that the plant is in an early stage of domestication with very few improved varieties. Identifying the true potential of jatropha requires separating the evidence from the hyped claims and half-truths (Shanker and Dhyani, 2006). 


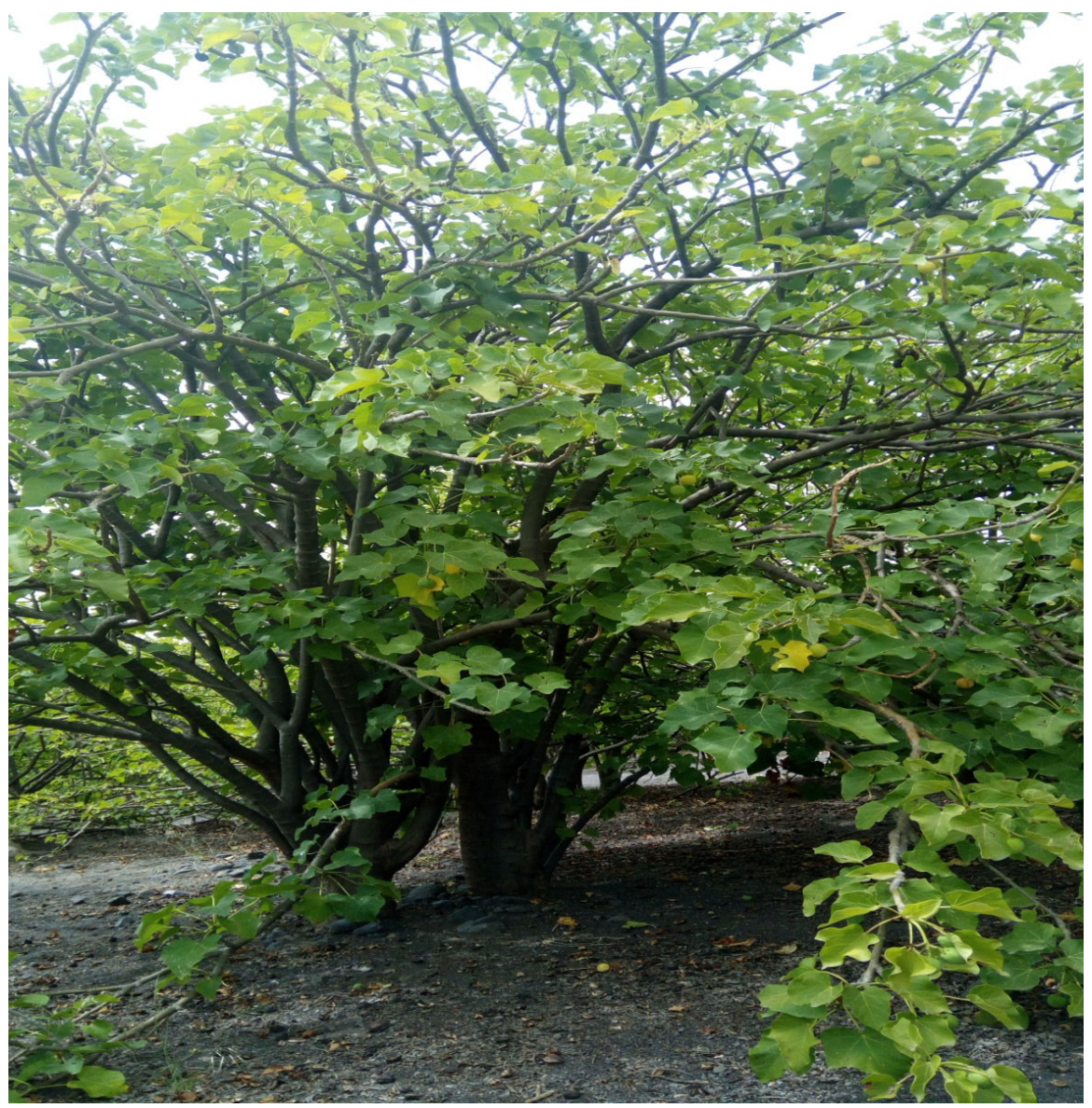

Source: field shoot from Alamata,Ethiopia jatropha plantation site

\section{MEDICINAL IMPORTANCE OF JATROPHA}

Various biologically active substances have been isolated and characterized from all parts of the plant. Their mechanisms of action have been studied in relation to a great number of applications of J.curcas in traditional medicine. Substances such as phorbol esters, responsible for the toxicity of J.curcas to animals and humans, have been isolated and their molluscicidal, insecticidal and fungicidal properties have been demonstrated in lab-scale experiments and field trials.

Newly developed biotechnological processes related to the exploitation of J. curcas include the genetic improvement of the plant, biological pest control, enzyme-supported oil extraction, anaerobic fermentation of the press cake and the isolation of antiinflammatory substances and wound-healing enzymes (Gübitz GM, Mittelbach M,1999).

The genus name Jatropha derived from the Greek jatrós (doctor), trophé (food), which implies medicinal uses. Jatropha curcas is a bush or small tree and belongs to euphorbiaceaefamily. This plant has been used traditionally for medicinal purposes. The plant possesses anti-inflammatory,antimetastatic, antitumor, coagulant and anti-coagulant (dose dependent), disinfectant, antiparasitic, woundhealing, insecticidal, pregnancy terminating activity and antidiarrhoeal effect. The main constituents of the plantare curcin, curcusone-B, curcain etc. Apart from this, the plant also contains toxic principle such astetramethylpyrazine (TMPZ) (.Sumit N Laxane eta.l ,2013).

According to Hartwell (1967-1971), the extract is used in folk remedies for cancer. Reported to be abortifacient, anodyne, antiseptic, cicatrizant, depurative, diuretic, emetic, hemostat, lactagogue, narcotic, purgative, rubefacient, styptic, vermifuge, and vulnerary physic nut is a folk remedy for alopecia, anasorca, ascites, burns, carbuncles, convulsions, cough, dermatitis, diarrhea, dropsy, dysentery, dyspepsia, eczema, erysipelas, fever, gonorrhea, hernia, incontinence, inflammation, jaundice, neuralgia, paralysis, parturition, pleurisy, pneumonia, rash, rheumatism, scabies, sciatica, sores, stomachache, syphilis, tetanus, thrush, tumors, ulcers, uterosis, whitlows, yaws, and yellow fever (Duke and Wain, 1981; List and Horhammer, 1969-1979). Guatemalans place heated leaves on the breast as a lactagogue. Cubans apply the latex to toothache. Colombians and Costa Ricans apply the latex to burns, hemorrhoids, ringworm, and ulcers. Barbadians use the leaf tea for marasmus, Panamanians for jaundice. Venezuelans take the root decoction for dysentery. Seeds are used also for dropsy, gout, paralysis and skin ailments. Leaves are regarded as antiparasitic, applied to scabies; rubefacient for 
paralysis, rheumatism; also applied to hard tumors. Latex used to dress sores and ulcers and inflamed tongues. Seed is viewed as aperient; the seed oil is emetic, laxative, purgative and for skin ailments; root decoction as a mouthwash for bleeding gums (Duke JA. 1983).

\section{1) Root}

The roots are used to make an antidote for snake bites (Oliver, 2006). The roots are used in decoction as mouth wash for bleeding gums and tooth ache as well as for eczema, scabies and ringworm. Venezuelans take the root decoction for dysentery (Morton, 1981).

Use of Jatropha roots in the treatment of diarrhoea is a common ethnobotanical practice in Konkan, a part of the Western coastal area of India. Roots of this species were undertaken for pharmacognostic studies and evaluation of antidiarrhoeal activity in albino mice. The methanol fraction after successive extraction showed activity against castor oil induced diarrhoea and intraluminal accumulation of fluid. It also reduced gastrointestinal motility after charcoal meal administration in albino mice. The results indicate that action of $\mathrm{J}$. curcus root methanol extract could be through a combination of inhibition of elevated prostaglandin biosynthesis and reduced propulsive movement of the small intestine (.Upadhye AS eta.l,2000)

Anti inflammatory activity of topical application of Jatropha curcas L. root powder in paste form in TPAinduced ear inflammation was confirmed in albino mice and successive solvent extraction of these roots was carried out by ether and methanol. The methanol extract exhibited systemic and significant anti inflammatory activity in acute carrageenan induced rat paw edema. It also showed activity against formalin-induced rat paw edema, turpentine-induced exudative changes and cotton pellet-induced granular tissue formation after oral treatment for 7 days in albino rats. Thus resultant anti inflammatory activity might be due to effects on several mediators and arachidonic acid metabolism involving cyclooxygenase pathway resulting in prostaglandin formation; anti-proliferative activity leading to reduction in granular tissue formation and leukocyte migration from the vessels (, Misar AV. J Ethnopharmacol 2004). Ashe of the burned roots is used as a salt substitute (Morton, 1981). Agaceta et al.; (1981) concluded that it has strong molluscicidal activity. Duke and Wain (1981) list it as homicide, piscicide, and raticide as well.

\section{2) Latex of Jatropha}

The latex cream of $J$. curcas possesses anti-inflammatory activity in wound healing process of mice skin (Muhammad Nur Salim etal 2018).The latex can also be used to remedy alopecia, anasora, burns, dropsy, eczema, inflammation, paralysis and yellow fever (Heller, 1996). Its latex contains alkaloids (jatrophine, jatrophen, jatrophore and curcain) which are anti-carcinogenic.

J. curcas Linn.is traditionally used as a haemostatic. Investigation of the coagulant activity of the latex of J. curcas showed that whole latex significantly $(\mathrm{P}<0.01)$ reduced the clotting time of human blood. Diluted latex, however, prolonged the clotting time: at high dilutions, the blood did not clot at all. This indicates that J. curcas latex possesses both coagulant and anticoagulant activities. Prothrombin time (PT) and activated partial thromboplastin time (APTT) tests on plasma confirm these observations. Solvent partitioning of the latex with ethyl acetate and butanol led to a partial separation of the two opposing activities: at low concentrations, the ethyl acetate fraction exhibited a procoagulant activity, while the butanol fraction had the highest anticoagulant activity.

The latex was strongly inhibitory to watermelon mosaic virus (Tewari and Shukla, 1982). Also Latex is applied topically to bee and wasp stings. Mauritians massage ascitic limbs with the oil. Cameroon natives apply the leaf decoction in arthritis (Watt and Breyer- Brandwijk, 1962). Cubans apply the latex to toothache. Colombians and Costa Ricans apply the latex to burns, hemorrhoids, ringworm, and ulcers. Latex is used to dress sores and ulcers and inflamed tongues (Perry, 1980), ( J Ethnopharmacol 2003). Latex applied topically to bee and wasp stings.

2.3) Jatropha Stem Stems of young leaves have been used to successfully treat urinary infections. The tender twig can also be used as atooth brush to clean the teeth (Gill, 1992; Hasfort, 2000).

\section{4) Jatropha Leaves}

Bacteriological and parasitologic tests were carried out on laboratory bench surfaces using the sap and crushed leaves of J. curcas. Observation showed that the sap exhibited germicidal actions on the growth of common bacteria of Staphylococcus, Bacillus and Micrococcus species on contact and retained such effects on treated laboratory bench surface for close to six hours after initial application. Ova of Ascaris lumbricoides and Necator americanus incubated in $50 \%$ and $100 \%$ concentrations of the sap at room temperature showed either no evidence of embryonation after 21 days in the case of A. lumbricoides, negation of hatchability in hookworm or complete distortion in both. The sap also exhibited strong inhibitory effect on normal larval growth of mosquito, but was highly toxic to mice when administered through oral or intraperitoneal routes. This may conclude that $\mathrm{J}$. 
curcas would provide a very cheap, readily available disinfectant and malaria vector control agent and should be commercially exploited (Ahmed OM etal,1979).

Making a compress from the leaves and placing it on the sore tooth will help relieve pains (RejoreandBatra, 2003). Sap from the leaves can also be rubbed on to the gum of babies to aid with teething. The tea from the leaves could help with the reduction of fever and help with jaundice and gonorrhea. Cameroon natives apply the leaf decoction in arthritis (Mujumdar AM etal,2004). Colombians drink the leaf decoction for venereal disease. Bahamans drink the decoction for heartburn. Costa Ricans poultice leaves onto erysipelas and splenosis.Colombians drink the leaf decoction for venereal disease. Bahamans drink the decoction for heartburn. Costa Ricans poultice leaves onto erysipelas and splenosis. Guatemalans place heated leaves on the breast as a lactagogue. Barbadians use the leaf tea for marasmus and Panamanians for jaundice. Leaves are regarded as antiparasitic, applied to scabies; rubefacient for paralysis, rheumatism; also applied to hard tumors (Hartwell, 1967-1971). According to Ochse (1980), "the young leaves may be safely eaten, steamed or stewed."

\section{5) Jatropha Plant Seed}

In South Sudan, the seed as well as the fruit is used as a contraceptive (List and Horhammer, 1969-1979). For homicides, pesticide, regicide and extracts are used in folk remedies for cancer (Aliyu, 2006). Aliyu (2006) furtherreported that J. curcas is abortifaceous, anodyne, antiseptic, cicatrizant, depurative, diuretic, hemostat, lactagogue, narcotic, purgative and rubefacient. Other ethnomedicinal uses of $J$. curcas include stryptic, vermifuge and vulnerary. It has also been reported as a folk remedy for alopecia, anasorea, ascites, burns, carbuncles, convulsions, cough, dermatitis, diarrhea, dropsy, dysentery, dyspepsia, eczema, fever, erysipelas, jaundice, paralysis, rashes, rheumatism, yellow fever, tetanus, ulcer, stomach ache, sores, heart burns, thrush, uterosis, whitlows and yaws. The plant is rich in many photochemical including xylose (seeds), vitex (bark), sovitexin (leaf), and curcusones (whole plant) (Osemene et al., 2013). Seeds are used also for dropsy, gout, paralysis, and skin ailments (Watt and Breyer-Brandwijk, 1962).

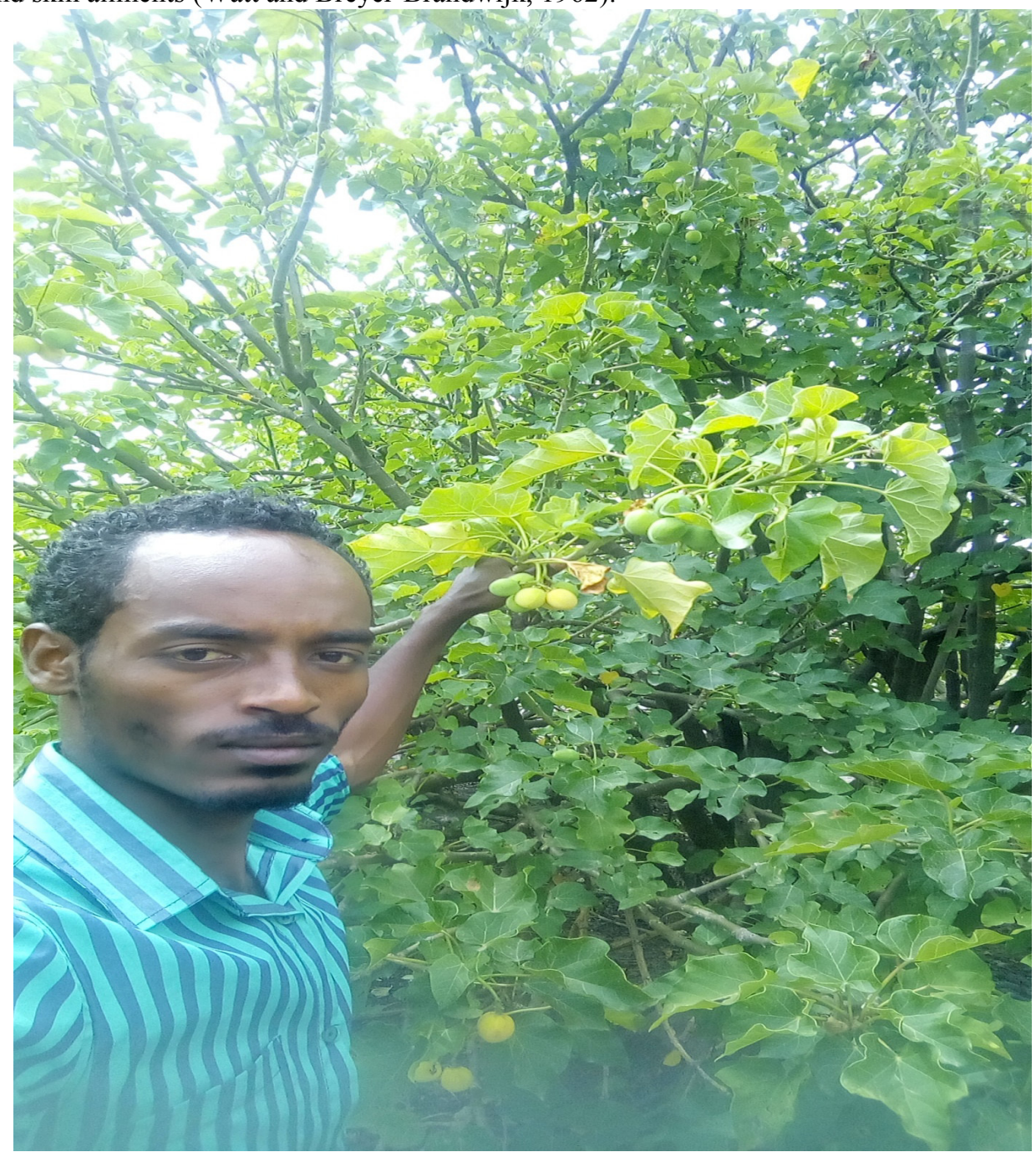

Source: field shoot from Alamata,Ethiopia jatropha plantation site 
Table 1 : chemical property of jatropha seed

\begin{tabular}{|l|l|l|l|l|}
\hline Material & Kernel (60\% of weight) & Shell (40\% of weight) & Meal & Soybean meal \\
\hline Crude protein & $22.2-27.2$ & $4.3-4.5$ & $56.4-63.8$ & 45.7 \\
\hline Lipid (crude fat) & $56.8-58.4$ & $0.5-1.4$ & $1.0-1.5$ & 1.8 \\
\hline Ash & $3.6-4.3$ & $2.8-6.1$ & $9.6-10.4$ & 6.4 \\
\hline Neutral detergent fibre & $3.5-3.8$ & $83.9-89.4$ & $8.1-9.1$ & 17.2 \\
\hline Acid detergent fibre & $2.4-3.0$ & $74.6-78.3$ & $5.7-7.0$ & 12.2 \\
\hline Acid detergent lignin & $0.0-0.2$ & $45.1-47.5$ & $0.1-0.4$ & 0.0 \\
\hline Gross energy (MJ/kg) & $30.5-31.1$ & $19.3-19.5$ & $18.0-18.3$ & 19.4 \\
\hline
\end{tabular}

Source: Trabi, 1998; Makkar et al., 1997

\section{6) Jatropha Plant Bark}

The extract from J. curcas accelerates the healing process by increasing the skin breaking strength, granulation tissue breaking strength, wound contraction, dry granulation tissue weight and hydroxyproline levels. A significant decrease in epithelization period was also observed.The histopathological examination of granulation tissue showed much advanced phase of healing, with more collagen, which has organized to form bundles (Shetty S. etal, 2006). Bark is also used as a fish poison (Watt and Breyer-Brandwijk, 1962).

\section{7) Extracted Oil of Jatropha}

Jatropha seed oil at various serial dilutions ranging from $0 \%$ to $2 \%(\mathrm{v} / \mathrm{w})$ at $0.5 \%$ intervals were evaluated for anti-ovipositional activity and long-term protective ability of treated cowpeas against the seed beetle Callosobruchus maculatus. The oil significantly $(\mathrm{P}<0.05)$ reduced oviposition by $\mathrm{C}$. maculatus in no-choice test in all the concentrations tested. Oviposition was significantly reduced at all the oil concentration evaluated. J. curcas oil also offers a 12-week protection for treated seeds since there was neither seed damage nor adult emergency in treated cowpea seeds. The results of this study suggest J. curcas has antioviposition and ovicidal effects on C. maculatus therefore making it a viable candidate for incorporation into pest control program of gain legumes (Adedire CO, etal, 2003).The oil obtained from jatropha is used for illumination, making soap and candles, adulterate of olive oil, and making Turkey red oil. Nuts can be strung on grass and burned like candlenuts (Watt and Breyer-Brandwijk, 1962). In India, pounded leaves are applied near horses' eyes to repel flies.

\section{INDUSTRIAL APPLICATION OF JATROPHA}

$J$. curcas is a promising species because of its useful and profitable by-products. The chemical composition of various parts of $J$. curcas plant, which has industrial applications, is given in Table 2. Jatropha oil has various uses and apart from its use as a biofuel, the oil has been used to produce soup, medicine and pesticides (Shanker and Dhyani, 2006). The utilization of various parts of $J$. curcas L. is reviewed here, to know the potentials for improving economic situation of various tropical and subtropical countries.

3.1) Fine Chemical and Catalyst: _J.curacas is one of an important raw material for extraction of fine chemicals and catalysts form different parts (root,cake,seed..).

Table 2. Chemical composition of different parts of jatropha curcas plant

\begin{tabular}{|c|c|}
\hline Various parts & Chemical composition with references \\
\hline Root & $\begin{array}{l}\beta \text {-sitosterol and its } \beta \text {-D-glucoside, marmesin, propacin, the curculathyranes } \mathrm{A} \text { and } \mathrm{B} \text { and the } \\
\text { curcusones A-D, diterpenoids jatrophol and jatropholone A and B, the coumarin tomentin, } \\
\text { the coumarino-lignan jatrophin as well as taraxerol [Naengchomnong et al., 1986, 1994]. }\end{array}$ \\
\hline Steam bark & $\beta$-Amyrin, $\beta$-sitosterol and taraxerol [Mitra et al., 1970] \\
\hline Leaves & $\begin{array}{l}\text { Flavaonoids apigenin, vitexin, isovitexin, dimmer of atriterpene alcohol }\left(\mathrm{C}_{63} \mathrm{H}_{117} \mathrm{O}_{9}\right) \text { and two } \\
\text { flavonoidal glycosides [Mitra et al., 1970; Khafagy et al., 1977; Hufford and Oguntimein, 1987] }\end{array}$ \\
\hline Aerial parts & $\begin{array}{l}\text { Organic acids (o and p-coumaric acid, } \mathrm{p} \text {-OH-benzoic acid, protocatechuic acid, resorsilic } \\
\text { acid, saponins and tannins, } \beta \text {-Amyrin, } \beta \text {-sitosterol and taraxerol [Hemalatha and } \\
\text { Radhakrishnaiah, 1993] }\end{array}$ \\
\hline Latex & $\begin{array}{l}\text { Curcacycline A, a cyclic octapeptide, Curcain (a protease) [Van den Berg et al., 1995; Nath } \\
\text { and Dutta, 1991] }\end{array}$ \\
\hline Seeds & $\begin{array}{l}\text { Curcin, lectin, phorbolesters, esterases (JEA) and lipase (JEB) [Stirpe et al., 1976; Adolf et } \\
\text { al., 1984; Makkar et al., 1997; Staubmann et al., 1999] }\end{array}$ \\
\hline $\begin{array}{l}\text { Oil cake and } \\
\text { kernel }\end{array}$ & $\begin{array}{l}\text { Phytates, saponins and trypsine inhibitor [Aregheore et al., 1997; Makkar and Becker, 1997; } \\
\text { Wink et al., 1997] }\end{array}$ \\
\hline
\end{tabular}

Source: A. K. M. A. Islam, 2010 
Two new esterases (JEA and JEB) and a lipase (JL) were extracted from the seeds of J .curas. Lipase activity was only found during germination of the seeds and increased to a maximum after 4 days of germination. All enzymes were found to be most active in the alkaline range at around $\mathrm{pH} 8$ and the purified (fractionated precipitation with ethanol and gel filtration) esterases were very stable at high temperatures. The molecular weight (SDSPAGE: sodium dodecyl sulfate polyacrylamide gel electrophoresis) of both esterases was determined to be 21.6-23.5 kDa (JEA) and 30.2 kDa (JEB) and the isoelectric point was 5.7- 6.1 for esterase JEA and 9.0 for esterase JEB. Most ions caused a negative influence on the activity of both esterases. Both esterases hydrolyzed tributyrin, nitrophenyl esters up to a chain length of $\mathrm{C} 4$ and naphtylesters up to a chain length C6. In transesterification reactions, JL was found to be most active at very low water activities $(0.2)$ and in high water activities, the lipase hydrolysed triglycerides into conversions above $80 \%$. JL is a potentially useful biocatalyst in the hydrolysis of triglycerides in organic solvents (Steiner W etal, 1999).

\section{2) Soap production}

The local production of soap is one of the most economically attractive uses of jatropha oil. The glycerin byproduct of the trans- esertification process can be used to make a high quality soap, or it can be refined and sold at a range of prices, depending on its purity, to be used in an immense range of products, including cosmetics, toothpaste, embalming fluids, pipe joint cement, cough medicine, and tobacco (as a moistening agent). The soap has positive effects on the skin and is therefore marketed for medicinal purposes. Jatropha oil is used mainly in the manufacture of high quality soap. According to the IPGI report, pressing of $12 \mathrm{~kg}$ of seeds yields $3 \mathrm{~L}$ of oil that is then transformed into soap, 28 pieces of soap of $170 \mathrm{~g}$ each, which is $4.76 \mathrm{~kg}$. This takes $5 \mathrm{~h}$ of work (estimated). The total input is added to US \$3.04. The soap can be sold for US $\$ 4.20$, and the resulting $9 \mathrm{~kg}$ of press cake is well appreciated as organic fertilizer and can be sold for US $\$ 0.27$; a total revenue of US $\$ 4.47$ (Benge,2006).

\section{3) Botanical Pesticide}

Extracts from all parts of the physic nut showed insecticidal properties on plants (Grainge and Ahmed, 1988; Consoli et al., 1989; Jain and Trivedi, 1997; Meshram et al., 1994). Most of the experiments done are still in experimental stage. The oil and aqueous extract from oil has potential as an insecticide. For instance, it has been used in the control of insect pests of cotton including cotton bollworm, and on pests of pulses, potato and corn (Kaushik and Kumar, 2004). The pesticidal action of the seed oil is also the subject of research of International Crops Research Institute for the Semi-Arid Tropics, (ICRISAT) in India. Jatropha caraculs is an important means for the preparation of pesticides(Wilson et al 2013)

\section{4) Fertilizer}

The byproduct of oil extraction from the seeds and kernels is called seed cake. Jatropha seed cake contains curcin, a highly toxic protein similar to ricin in Castor, making it unsuitable for animal feed. However, it does have potential as good organic manure (Staubmann et al., 1997; Gubitz et al., 1999), replacing chemical fertilizer since it has nitrogen content (Kumar and Sharma, 2008) similar to that of neem oil cake, castor bean, cow/chicken manure (Table 4). The nitrogen content ranges from 3.2 to 3.8\% (Juillet et al., 1955; Moreira, 1979; Vohringer, 1987). Application showed phytotoxicity, expressed as reduced germination, when high rates of up to 5 tonnes ha $^{-1}$ was used. The GTZ project in Mali carried out a fertilizer trial with pearl millet where the effects of manure ( 5 tonnes/ha), physic nut oil cake ( 5 tonnes/ha) and mineral fertilizer (100 kg ammonium phosphate and $50 \mathrm{~kg}$ urea/ha) on pearl millet were compared (Henning et al., 1995). Pearl millet yields per hectare were maximum $(1366 \mathrm{~kg})$ in physic nut oil cake treatment. As the costs for mineral fertilizer were higher than those of the oil cake (Henning et al., 1995), it is appreciated by the farmers and can be sold for 10 FCFA per kg (US $\$ 0.02 / \mathrm{kg}$ ).

Table 3. Fertilizer value of Jatropha curcas oil cake, root and other manures

\begin{tabular}{|l|l|l|l|l|l|}
\hline $\begin{array}{l}\text { Fertilizer } \\
\text { properties }\end{array}$ & $\begin{array}{l}\text { Jatropha curcas } \\
\text { oil cake (\%) }\end{array}$ & $\begin{array}{l}\text { Jatropha curcas } \\
\text { root (\%) }\end{array}$ & $\begin{array}{l}\text { Cow dung } \\
(\%)\end{array}$ & $\begin{array}{l}\text { Neem oil } \\
\text { cake (\%) }\end{array}$ & $\begin{array}{l}\text { Chicken manure } \\
(\%)\end{array}$ \\
\hline Nitrogen & $3.2-4.44$ & 2.16 & 0.97 & 5.00 & 3.04 \\
\hline Phosphorus & $1.4-2.09$ & 0.08 & 0.69 & 1.00 & 6.27 \\
\hline Potassium & $1.2-1.68$ & 2.18 & 1.66 & 1.50 & 2.08 \\
\hline Moisture & 4.58 & - & 9.70 & - & 10.19 \\
\hline
\end{tabular}

Source:Delgado and Parado 1989

\section{5) Raw material for dye}

The bark of $J$. curcas yields a dark blue dye which is reported to be used for coloring cloth, fishing nets and lines. The dye may be extracted from leaves and tender stems and concentrated to yellowish syrup or dried to blackish brown lumpy mass. The dye imparts to cotton different shades of tan and brown which are fairly fast. Further 
research in this field can open up great possibilities.

\section{6) For Food Consumption}

Jatropha can be toxic when consumed and many cases of poisoning with physic nut are reported in the literature (Siegel, 1893). However, a non-toxic variety of jatropha is reported to exist in some provenances of Mexico and Central America, said not to contain toxic Phorbol esters (Makkar et al., 1998a, b). This variety is used for human consumption after roasting the seeds/nuts (Delgado and Parado, 1989), and "the young leaves may be safely eaten, steamed or stewed." When grown from seeds, the plants are edible for the first 3 months, since the toxic material has not been developed yet. Levingston and Zamora (1983) report that jatropha seeds are edible once the embryo has been removed; nevertheless on principal, consumption of seeds should be avoided. Therefore, it will serve for food security achievements in poor countries. Non-toxic variety of jatropha could be a potential source of oil for human consumption, and the seed cake can be a good protein source for humans as well as for livestock (Becker, 1996; Makkar and Becker, 1997, 1999; Aregheore,2003).

\section{7) Production of biofuel}

Jatropha curcas oil is one of the feedstock to be biofuel production. Jatropha is very important in the production of biodiesel since it is a nonedible plant and will not cause competition on human food. Advances in the use of biodiesel as an alternative fuel are aimed at providing cheap and renewable energy, which is easy to manufacture and more importantly clean and more environmentally friendly (C. L. Peterson etal, 1999).

The conventional process for biofuel production is based on the alcoholysis of jatropha curcas oils in the presence of base catalyst carried out in batch stirred reactors. This process needs more 2 hours for complete reaction of oil to biofuel( Muh Irwan etal, 1983). Various features like, ease of production, sustainability and environmentally friendly nature of biomass draw attention as a potential renewable energy to replenish fossil fuel demand. Among the crops identified as energy crops for first generation biofuels, Jatropha curcas L. (JCL) has been acknowledged as one of the promising candidates (Del Greco, etal, 2008). Parts of Jatropha plant, like wood, fruit shells, seed husks and kernels, are used to produce energy (Singh, R., et al, 2008). Raw oil is the major resource obtained from Jatropha. Depending on the variety/cultivars, decorticated seeds contain 40-60\% oil.

\section{8) other uses}

Jatropha oil is also used to soften leather and lubricate machinery (e.g. chain saws). If seed cake is available in large quantities, it can also be used as a fuel for steam turbines to generate electricity. Apart from the bio-diesel application, the oil finds the application in cosmetic industries, for the manufacture of candles and soap. The extraction of the biodiesel after transesterification of the seed oil, leads to two main by-products that is glycerol and press or oil cake. Glycerol has many useful industrial applications as a raw material for the synthesis of 1, 3 propane-diol and other polymeric materials (Sharma, 2008). The bark of jatropha contains tannin. It can also have the honey production potential as the flowers can attract bees.

Optimum growing conditions are found in areas of 1000 to $1500 \mathrm{~mm}$ annual rainfall, with temperatures of $20^{\circ} \mathrm{C}$ to $28^{\circ} \mathrm{C}$ with no frost, and where the soils are free-draining sands and loams with no risk of waterlogging. Propagation is typically from seed. Cuttings offer the benefit of uniform productivity with the disadvantage that they do not generally develop a tap root. The production of clonal and disease-free plants using tissue culture is not yet a commercial reality. Attention to crop husbandry and adequate nutrition and water are essential to achieving high yields. Pruning is important to increase the number of flowering branches.

\section{SOCIAL AND ENVIRONMENTAL IMPORTANCE OF JATROPHA}

The Jatropha System is an integrated rural development approach. By planting Jatropha hedges to protect gardens and fields against roaming animals, the oil from the seeds can be used for soap production, for lighting and cooking and as fuel in special diesel engines. Although optimum ecological conditions for jatropha production are in the warm subhumid tropics and subtropics, jatropha's ability to grow in dry areas on degraded soils that are marginally suited for agriculture makes it especially attractive. In addition, jatropha can be used as a living fence to keep out livestock, control soil erosion and improve water infiltration. The waste products from jatropha biodiesel production can be used as fertilizer and for producing biogas, and the jatropha seedcake can potentially be used for livestock feed.

In this way the Jatropha System covers 4 main aspects of rural development:

$\checkmark$ promotion of women (local soap production);

$\checkmark$ Poverty reduction (protecting crops and selling seeds, oil and soap).

$\checkmark$ erosion control (planting hedges);

$\checkmark \quad$ energy supply for the household and stationary engines in the rural area;

The obvious advantage of this system is that all the processing procedure, and thus all added value, can be 
kept within the rural area or even within one village. No centralized processing (like in the cotton industry) is necessary.

Government policy in support of rural development, the third main driver of biofuel growth, has been enabled by the large demand for biofuel feedstocks and the import substitution potential of biofuels. In OECD countries, biofuels are seen as a new market opportunity due to their ability to absorb surplus agricultural production while maintaining productive capacity in the rural sector. In developing countries, biofuels can contribute to rural development in three main areas: employment creation, income generation and by replacing traditional biomass, which is an inefficient and unsustainable energy resource, with modern and sustainable forms of bioenergy.

Economies of scale and the vertical integration required for biofuel production allow little scope for small farmers to benefit. This is particularly true in bioethanol production and will be even more so with second- and third-generation biofuels, unless specific efforts are made to include small farmers in biofuel production schemes. There is more potential for biodiesel to be produced on a smaller scale, although maintaining consistent quality standards will be a problem. Small-scale production of straight vegetable oil requires the least economies of scale and has the greatest potential to benefit small farmers and rural development.

\section{1) Erosion control as hedge plant and biofence}

Jatropha is planted in the form of hedges around gardens or fields to protect the crops against roaming animals like cattle orgoats;

Jatropha hedges are planted to reduce erosion caused by waterand/or wind;

Jatropha is planted to demarcate the boundaries of fields andhomesteads;

Jatropha plants are used as a source of shade for coffee plants in Cuba;

In Comore islands, in Papua New Guinea and in Uganda Jatropha plants are used as a support plant for vanilla plants;

\section{2) Climate change Mitigation}

The need to slow or reverse global warming is now widely accepted. This requires reduction of greenhouse gas (GHG) emissions, especially reduction of carbon dioxide emissions. Using cultivated and non-domesticated plants for energy needs instead of fossilized plant remains such as mineral oil and coal reduces the net addition of $\mathrm{CO} 2$ to the atmosphere. In addition, biodiesel produces fewer particulates, hydrocarbons, nitrogen oxides and sulphur dioxides than mineral diesel and therefore reduces combustion and vehicle exhaust pollutants that are harmful to human health.

\section{RECOMMENDATION AND CONCLUSION}

$J$. curcas is a "miracle tree" and certainly a highly interesting plant with potential uses, particularly as biofuel to help in combating the energy crisis throughout the world and generate income in rural areas of developing countries. The jatropha plant can become globally competitive due to the fact that it belongs to a non-edible category and does not compete with food. Jatropha oil is a clean fuel reducing greenhouse gas emissions, has greater lubricity and reduces engine wear. Pure jatropha biodiesel is non-toxic in nature. The literature findings reveals several successful application of jatropha which includes functions like soil water conservation, soil reclamation, erosion control, living fences, green manure, lightning fuel, local use in soap production, insecticide and as raw material for pharmaceutical and cosmetic industries. From the above discussions, it is clear that the jatropha plant has capabilities to provide the products for different applications apart as a diesel substitute which needs to be captured and improved. Jatropha is economically viable not only to the growers but also to the processors and end users. To the rural society, the crop can create regular employment opportunities, as it provides never ending marketing potential. The research on the utilization of the by-products of jatropha namely seed husk, seed kernel, glycerol, etc. in the material manufacturing area needs to be explored.

Newly developed biotechnological processes related to the exploitation of J. curcas include the genetic improvement of the plant, biological pest control, enzyme-supported oil extraction, anaerobic fermentation of the press cake and the isolation of antiinflammatory substances and wound-healing enzymes.

In General Jatropha curcas is a quick-growing and popular tree. It is a traditionally important medicinal plant and having various commercial applications.

Jatropha curcas having anti-inflammatory, anti-metastatics, anti-tumor, coagulant and anti-coagulant, disinfectant / anti-parasitic, wound healing, insecticidal, pregnancy terminating activity and anti-diarrhoealeffect.

The main constituents are curcin, curcusone B, curcain, campesterol and curcacycline-A.

The plant having toxic potential, toxicity is due to curcin and tetramethylpyrazine. The seed oil contains phorbol esters, known to cause a large number of biological effects. However, the toxicity can be managed by deacidification and bleaching of phorbolesters.

Rehabilitating degraded areas and protecting the land from wind erosion: Preliminary studies have shown 
that it could prove Avery promising species for rehabilitating degrade areas and protecting the land from wind erosion when introduced in dry areas within the framework of watershed management. These properties make this plant as a highly commercial one and as an alternative energy source to local as well as to world community.

\section{REFERENCE}

Agarwal D, Agarwal AK (2007). Performance and emissions characteristics of Jatropha oil (preheated and blends) in a direct injection compression ignition engine. Appl. Therm. Eng., 27: 2314- 2323.

Aregheore EM, Makkar HPS, Becker K (1997) Lectin activity in toxic and non-toxic varieties of $J$. curcas using a latex agglutination test. In: Gubitz, G.M., Mittelbach, M., Trabi, M. (Eds.), Biofuels and Industrial Products from Jatropha curcas. DBV Graz, pp.65-69.

Aregheore EM, Becker K, Makkar HPS (2003). Detoxification of a toxic variety of Jatropha curcas using heat and chemical treatments, and preliminary nutritional evaluation with rats. S. Pac. J. Nat. Sci., 21: 50-56.

Azam MM, Waris A, Nahar NM (2005). Prospects and potential of fatty acid methyl esters of some nontraditional seed oils for use as biodiesel in India. Biomass and Bioenergy, 29: 293-302

Basker T (1993). Experimental Investigation on the use of vegetable oil and vegetable oil esters in a low heat rejection engine. M.S. thesis. I.C.E. Lab, IIT, Madras-36.

Becker K (1996). Effect of different treatments on level of toxins in Jatropha curcas meal and effect of feeding on growth of fish (carp), rats and chickens. A report. Institute for Animal Production in the Tropics and Subtropics 480: 27 University of Hohenheim, Stuttgart, Germany(kbecker@uni-hohenheim.de).

Benge M (2006). Assessment of the potential of Jatropha curcas, (biodiesel tree,) for energy production and other uses in developing countries (www.echotech.org). Senior Agroforestry Officer, USAID (Ret.) bengemike@aol.com, Posted on ECHO ${ }^{\text {ee }}$ s website with permission of the author. July 2006 and updated August 2006.

Consoli RAGV, Mendes NM, Pereira JP, Santosh VS, Lemounier MA (1989). Influence of several plants extracts on the oviposition behaviour of Aedis fluviatilis (Lutz) in the laboratory. Memorias-Do- InstitutoOswaldo-Cruz, 84(1): 47-52.

C. L. Peterson, J. C. Thompson, J. S. Taberski, D. L. Reece, and G. Fleischman, "Long-range on-road test with twenty-percent rapeseed biodiesel," Applied Engineering in Agriculture, vol. 15, no. 2, pp. 91-101, 1999.

Del Greco, G.V. and L. Rademakers, The jatropha energy system: an integrated approach to decentralized and sustainable energy production at the village level. Ingegneria Senza Frontiere (Engineers Without BordersItaly). Accessed on-line, 2008. 22.

Dalziel JM (1955). The Useful Plants of West-Tropical Africa. Crown Agents for Oversea Governments and Administration, London, p. 147.

Dehgan B (1984). Phylogenetic Significance of Interspecific Hybridization in Jatropha (Euphorbiaceae). Systematic Bot., 9(4): 467-478.

Dehgan B, Webster GL (1979) Morphology and Intrageneric Relationships of the Genus Jatropha Euphorbiaceae). 74. University of California Publications in Botany.

Delgado Montoya JL, Parado Tejeda E (1989). Potential multipurpose agroforestry crops identified for the Mexican Tropics. In: Wickens, GE, Haq, N, Day P (Eds.), New Crops for Food and Industry. Chapman and Hall, London, pp.166-173.

Duke JA (1985). Medicinal plants. Sci., 229: 1036

Duke JA (1988). CRC Handbook of Medicinal Herbs. CRC Press, Boca Raton, FL, pp. 253-254.

Fairless D (2007). Biofuel: the little shrub that could - may be. Nature. 499: 652-655.

Foidl N, Eder P (1997). Agro-industrial exploitation of J. curcas. In: Biofuels and Industrial Products from Jatropha curcas. Giibitz, G.M., Mittelbach, M., Trabi, M. (Eds.), pp. 88-91, DBV Graz, Austria.

Foidl N, Goidl G, Sanchez M, Mittelbach M, Hackel S (1996). Jatropha curcas L. as a source for the produciton of biofuel in Nicaragua. Bioresource Tech., 58: 77-82.

Grainge M, Ahmed S (1988). Handbook of Plants with Pest-control Properties, Wiley-Interscience, New York.

Gubitz GM, Mittelbach M, Trabi M (1999). Exploitation of the tropical oil seed plant Jatropha curcas L. Bioresources Technol., 67: 73-82.

Gubitz M, Mittelbach, Trabi M (1997). Biofuels and industrial products from Jatropha curcas. Proceedings from a Symposium held in Managua, Nicaragua (Eds). Graz, Austria: Technical University of Graz, Austria, pp. 88-91.

Heller J (1996). Physic nut. Jatropha curcas L. Promoting the conservation and use of underutilized and neglected crops. Institute of Plant Genetics and Crop Plant Research (IPGRI), Gatersleben/International Plant Genetic Resources Institute, Rome, Italy, p.66.

Hemalatha A, Radhakrishnaiah M (1993). Chemosystematics of Jatropha. J. Econ. Taxonom. Bot., 17: 75-77.

Henning RK (2004). Integrated rural development by utilization of Jatropha curcas as raw material and as renewable energy. Rothkreuz II, D-83138, Weissensberg, Germany. 
Henning R, Samake F, Thiero I (1995). The nutrient value of Jatropha meal. Bamako, Mali. Projet Pourghere DNHE-GTZ..

Hufford CD, Oguntimein BO (1987). Non-polar constituents of Jatropha curcas. Lloydia, 41: 161-165.

Jain C, Trivedi PC (1997). Nematicidal activity of certain plants against root-knot nematode, Meloidogyne incognita infecting chickpea. Annals of Plant Protect. Sci., 5:171-4.

Jones N, Miller JH (1991). Jatropha curcas: A multipurpose species for problematic sites. Land Resour. Ser., 1: 1-12.

Jones N, Miller JH (1992). Jatropha curcas: a multipurpose species for problematic sites. World Bank, Washington DC, USA, ASTAG Technical Papers - Land Resources. 1: 12.

Jones N, Miller JH (1993). Jatropha Curcas, a Multipurpose Species for Problematic Sites. Washington, D.C.: The World Bank.

Juillet A, Suspllugas J, Courp J (1955). The sesame, In: Oilseeds and cake, Biological Encyclopedia, The Knight, Paris, pp. 552-562.

Katwal RPS, Soni PL (2003). Biofuels: an opportunity for socioeconomic development and cleaner environment. Indian Forester. 129: 939-949.

Levingston R, Zamora R (1983). Medicine trees of the Tropics. Unasylva, 35(140): 7-10.

Makkar HPS, Becker K (1997). Jatropha curcas toxicity: identification of toxic principle(s). Proceedings 5th International Symposium on Poisonous Plants, San Angelo, Texas, USA, p. 19-23.

Makkar HPS, Becker K (1999). Nutritional studies on rats and fish (carp Cyprinus carpio) fed diets containing unheated and heated Jatropha curcas meal of a non-toxic provenance. Plant Foods Hum. Nutr., 53: 183-102.

Muh. Irwan, Ramli Thahir, Arief Adhiksana, Marlinda, and Ramli "The production of biofuels from jatropha curcas oil using ultrasound energy", AIP Conference Proceedings 1983, 020025 (2018)

Naengchomnong W, Thebtaranonth Y, Wiriyachitra P, Okamoto KT, Clardy J (1986). Isolation and structure determination of four novel diterpenes of Jatropha curcas. Tetrahed. Lett., 27: 2439-2442.

Singh, R., et al., SPRERI experience on holistic approach to utilize all parts ofJatropha curcasfruit for energy. Renewable Energy, 2008. 33(8): p. 1868-1873.

Stirpe F, Pession, Brizzi A, Lorenzoni E, Strochi P, Montanaro L, Sperti S (1976). Studies on the proteins from the seeds of Croton tigilium and Jatropha curcas. Biochem., J. 156: 1-6.

Takeda Y (1982). Development study on Jatropha curcas (sabu dum) oil as a substitute for diesel oil in Thailand. Interim Report of the Ministry of Agriculture. Thailand.

Vinayak P, Kanwarjit S (1991). Oil gloom to oil boom (Jatropha curcas). In: Agro-Forestry Federation Maharastra. Shree press, India.

Wink M, Koschmieder C, Sauerwein M, Sporer F (1997). Phorbol esters of J. Curcas-biological activities and potential applications. In: Gubitz, G.M., Mittelbach, M., Trabi, M. (Eds.), Biofuels and Industrial Products from Jatropha curcas. DBV Graz, pp. 160-166. 